\title{
DETERMINANTS OF ADAPTATION MEASURES ON CLIMATE CHANGE. A CASE OF SMALL-SCALE MAIZE FARMERS IN THE NORTH-WEST PROVINCE OF SOUTH AFRICA
}

\author{
OdUNIYI, O. S. ${ }^{*}$ - ANTWI, M. A. - TEKANA, S. S. \\ Department of Agriculture and Animal Health, University of South Africa, Florida Campus, \\ Florida, South Africa \\ (e-mails:antwima@unisa.ac.za,tekanss@unisa.ac.za) \\ *Corresponding author \\ e-mail: sammiey2007@yahoo.com \\ (Received 10 $0^{\text {th }}$ Apr 2019; accepted $2^{\text {nd }}$ Jul 2019)
}

\begin{abstract}
Adaptation to climate change varies according to regions, it could be effective in relation to people and their locations. Adaptation to climate change in sub-Saharan Africa is different from that of developed countries, as resources are limited. This study was conducted in Ngaka Modiri Molema District Municipality in North West Province of South Africa. This study examined the determinants of climate change adaptation strategies among rural farmers' households in the study area. A total number of 346 questionnaires were administered to the farmers in the district using the stratified random sampling technique. Data were captured and analyzed using SPSS and EVIEWS software. Multicollinearity analysis was first performed to remove highly correlated variables from the model followed by the use of Tobit regression analysis. The results of the analysis indicated that farm size $(p<0.01)$, gender $(p<0.01)$, type of farm ( $p<0.05)$, farm ownership ( $p<0.05)$, land acquisition $(p<0.01)$, source of climate change information $(p<0.01)$, support received on climate change $(p<0.1)$, and adaptation barrier were statistically significant $(\mathrm{p}<0.01)$ and influenced climate change adaptation strategies. The study concluded that to support climate change adaptation among the rural farmers in the study area, considerable attention should be paid to understanding the socio-economic characteristics of the rural households, source of information and support received on climate change.
\end{abstract}

Keywords: adaptive capacity, Tobit regression model, climate change, Ngaka Modiri Molema District Municipality

Abbreviations: IPCC: Intergovernmental Panel on Climate Change, FAO: Food and Agriculture Organization, SSA: Sub Saharan Africa, LRAD: Land Redistribution for Agricultural Development, PLAS: Proactive Land Acquisition Strategy, UNDP: The United Nations Development Programme

\section{Introduction}

Climate change is real, perhaps one of the most serious environmental threats facing agriculture and rural livelihoods in Sub-Saharan Africa (SSA). Year in year out, it has become clearer that change in weather is happening at a rapid pace and it will have a profound severe negative impact on agriculture, management of natural resources and consequently on livelihood and food security. Climate change has significantly affected global agriculture in the $21^{\text {st }}$ century (Ochieng et al., 2016). The effects of climate change on agricultural production and livelihood is expected to intensify over time, and to vary across countries and regions (Food and Agricultural Organization of the United Nations, FAO, 2016). Climate change could impair economic growth and other aspects of human and natural well-being (Butler, 2018).

Climate change is known to be an important challenge facing African countries. The impact is largely due to low income, greater reliance on climate-sensitive sectors such as agriculture, and weak capacity to adapt to the changing climate. Agriculture in sub- 
Saharan Africa continues to suffer from climate change due to the temperature rising and rainfall frequency and intensity fluctuating (Winifred et al., 2018). Climate change has negatively impacted on SSA countries because of their low human adaptive ability to foresee increases in tremendous events resulting from widespread poverty, heavy reliance on rain-fed agriculture, lack of economic and technological resources, insufficient safety nets and educational progress (Osumanu et al., 2017). According to Adebayor (2012), the effects of climate change, economically, socially and environmentally, have been a bane on sustainable agricultural production and food security in SSA endangering the livelihood of two-thirds of the population who work within the agricultural sector. It is projected that cereal crop may decrease yield in subSaharan Africa due to intensifying water stress and frequent incidence of diseases, pests and weeds outbreaks (Niang et al., 2014).

Southern Africa is expected to experience an increase in temperature and disruption in rainfall patterns as well as an increased frequency of extreme climate events such as drought and floods as a result of climate change. South Africa inclusive, is vulnerable to climate change and variability due to a high increase in temperature resulting in the frequent occurrence of drought, shortage of underground water, scarcity and spatial variability of rainfall pattern (Pereira, 2017). South Africa has been experiencing an increase in warmer days and more decrease in the number of cooler days (Davis et al., 2016). According to Linus et al. (2014), it was reported that between 1960 to 2050 the air temperatures in South Africa are expected to increase by $2{ }^{\circ} \mathrm{C}$ on average, while atmospheric carbon-dioxide levels are expected to increase by about $235 \mathrm{ppm}$ (from 315 to $550 \mathrm{ppm})$.

The higher temperature is expected to increase crop heat stress and evapotranspiration demand in the North West Province of South Africa. The impacts are expected to affect natural resources such as air and water, which are considered to be the most critical factor associated with climate change. A report by Kiker (2015), on climate change synthesis on vulnerability and adaptation assessment, revealed that South Africa including North West Province is experiencing climate change which affects the water and air required by crops for survival. According to Blignaut et al. (2009), North West is considerably warmer with evidence that the future temperature will increase than normal which could make the region susceptible to marked reductions in maize production.

Notably, North West Province is one of the largest maize producers in the country (The South African Agricultural Baseline, 2011). The impact of climate change on the production of maize in the study area has resulted in low maize production coupled with a shortage of food and low income. This unpleasant situation in the study area has escalated into maize importation rather than exportation that the country was known of in the past. A report by Sensako (2015), established that South Africa was compelled to import 934,000 metric tons of yellow maize, which was worth about $\$ 137$ million at current international prices, from countries such as Argentina and Ukraine in 2015 spanning through the end of March 2016 as drought reduced the maize yield. Therefore, there is no gainsaying that the examination of the adaptation measures that farmers need to employ in order to cope with climate change to fully maximize the production of maize which is a staple food in North West Province of South Africa becomes necessary.

Without appropriate responses, climate change is likely to constrain economic development and poverty reduction efforts. Adaptation strategies are needed as a tool to 
promote livelihood in rural communities. Adaptation is one major policy option for reducing the negative impact of climate change. Since, Sub Saharan Africa is predicted to be among the most vulnerable regions to climate change (IPCC, 2014), and because of the reliance on rainfall and other natural systems, smallholder rural households, who constitute $65 \%$ of the total population in SSA are the primary victims of climate change. Some coping mechanisms must be in place to adapt to climate change. In recent years, the determinants to climate change adaptation have been limited, and this has become a key concern to farmers, researchers, and policymakers. The available empirical evidence on the determinants of climate change adaptation among rural household farmers have been on large scale and extremely disintegrated (Osumanu et al., 2017). To ensure a better understanding of smallholder rural households' vulnerability and factors determining climate change adaptation, there is a need to investigate the factors responsible.

The objective of this study is to identify and provide a comprehensive understanding of different factors that determine adaptation to climate change among rural households in the study area. The significance of this study is that the findings will assist in directing specific and appropriate measures in combating the factors that affect climate change adaptation strategies in the study area. This would also help to provide improved supervision on appropriate interventions to enhance the resilience of agriculturedependent households and communities.

\section{Materials and methodology}

The study was carried out in Ngaka Modiri Molema District Municipality of the North-West Province. The province lies in the north of South Africa on the Botswana border, with the Kalahari Desert to the west, Gauteng province to the east and the Free State to the south. North West province is the fourth smallest province in the country. It consists of four district municipal councils (Ngaka Modiri Molema District Municipality, Bojanala Platinum District Municipality, Dr. Ruth Segomotsi Mompati District Municipality, and Dr. Kenneth Kaunda District Municipality) which are in turn divided into 18 local municipalities. The province takes up about 8.7 percent of South Africa's land area $\left(106512 \mathrm{~km}^{2}\right.$ ), with mining being the major contributor to the Province economy followed by farming activities in which maize is predominantly planted.

Data were collected from Ngaka Modiri Molema district municipality, which consists of 5 local municipalities as shown in Figure 1. The list of small and emerging maize farmers in the district comprising about 575 farmers was obtained from Department of Agriculture, Forestry and Fisheries (DAFF) and also from Grain SA. Raosoft sample size calculator was used to determine the sample size from the population of the small and emerging maize farmers in the study area. The sample size calculator took into account the confidence level, the response distribution and the margin of error as indicated below:

$$
\begin{gathered}
\mathrm{x}=Z(c / 100)^{2} r(100-r) \\
\left.\mathrm{n}=N x /(N-1) E^{2}+x\right) \\
\mathrm{E}=\operatorname{Sqrt}\left[{ }^{(N-n) x} / n(N-1)\right]
\end{gathered}
$$




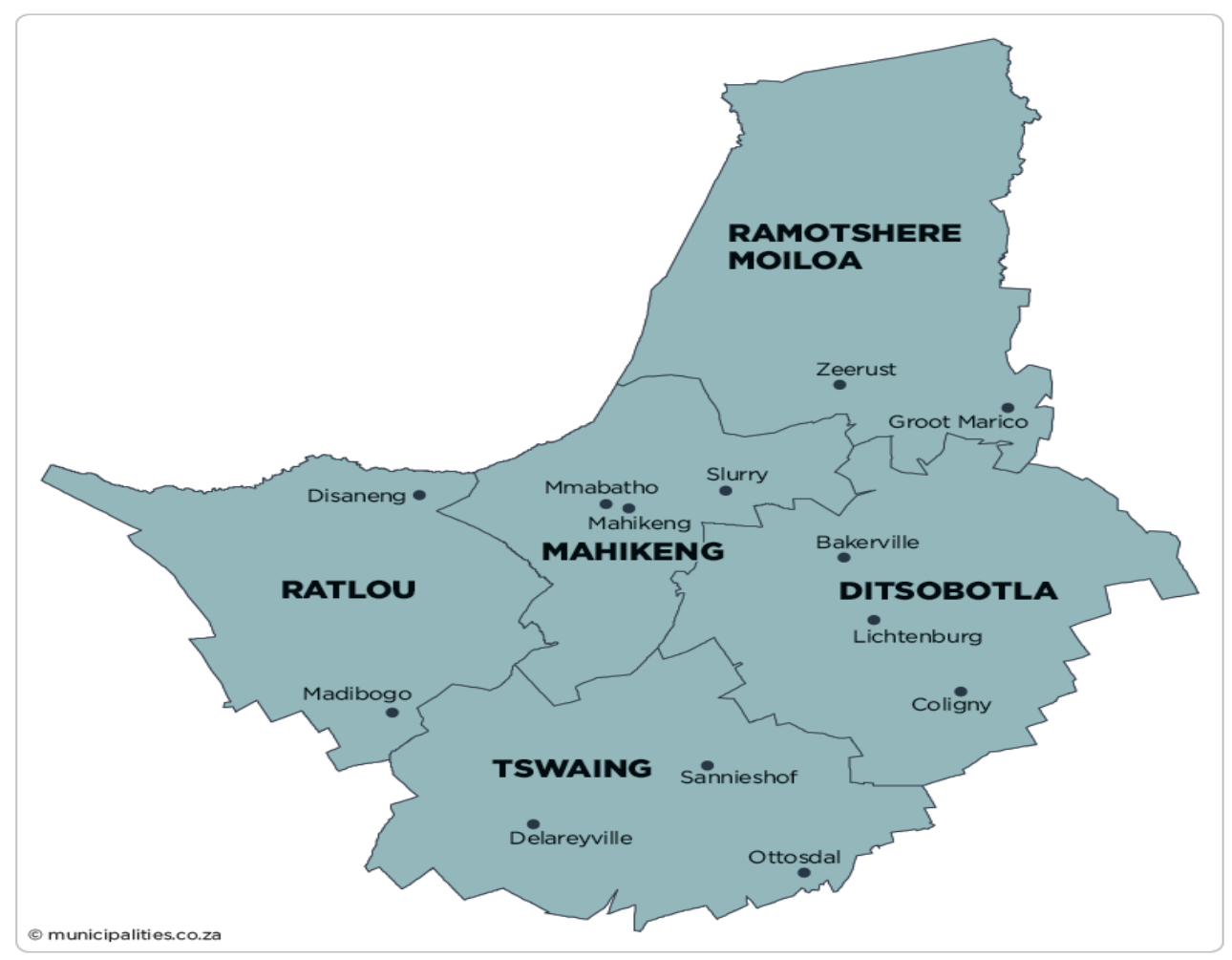

Figure 1. Map of Ngaka Modiri Molema District Municipality. (Source: Municipal Demarcation Board, 2010)

A total number of 346 questionnaires were administered to the farmers in the district using the stratified random sampling technique. This technique was employed to group the population of the farmers from the 5 local municipalities in the district into strata. Thereafter, random sampling was used to select from each stratum. A specific number of the sample size was selected from each stratum as shown in Table 1.

Table 1. Data collection according to the selected local municipalities. (Source: author's computation, 2017)

\begin{tabular}{c|c|c}
\hline $\begin{array}{c}\text { Stratum (local municipalities in } \\
\text { the district) }\end{array}$ & $\begin{array}{c}\text { The population of small scale } \\
\text { maize farmers }\end{array}$ & Selected sample size \\
\hline Tswaing & 200 & 132 \\
Ditsobotla & 150 & 109 \\
Mahikeng & 100 & 80 \\
Ratlou & 15 & 15 \\
Ramotshere Moiloa & 10 & 10 \\
\hline
\end{tabular}

The questionnaires consisted of a logical flow of questions related to household socio-economic characteristics (demography), climate change adaptation information. The questionnaires were explained to the local extension officers before the survey because they understood the farmers better and could translate the questions into the local language. Face to face interviews and focus group discussions were conducted in each local municipality where each session lasted for about $45 \mathrm{~min}$. 
The data were captured and analyzed using EVIEWS software. Multicollinearity analysis was employed to remove variables that are correlated to each other from the wide list of variables obtained from the questionnaires as shown in Table 2. A Tobit regression model was used to identify the factors that determine adaptation to climate change in the study area.

Table 2. Multicollinearity analysis. (Source: author's computation, 2017)

\begin{tabular}{c|c|c}
\hline \multirow{2}{*}{ Variables } & \multicolumn{2}{|c}{ Collinearity statistics } \\
\cline { 2 - 3 } & Tolerance & VIF \\
\hline Number of years of farming & 0.578 & 1.731 \\
Farm size & 0.731 & 1.367 \\
Household size & 0.760 & 1.315 \\
Gender & 0.816 & 1.225 \\
Household marital status & 0.706 & 1.416 \\
Education level & 0.602 & 1.661 \\
Farming as major income & 0.567 & 1.763 \\
Types of farm & 0.787 & 1.270 \\
Who manages the farm & 0.919 & 1.088 \\
Who owns the farm & 0.799 & 1.251 \\
Land acquisition & 0.741 & 1.350 \\
Climate change awareness & 0.748 & 1.337 \\
Source of climate change information & 0.707 & 1.414 \\
Climate change information through extension services & 0.723 & 1.382 \\
Channel of information received on climate change & 0.658 & 1.519 \\
Support received on climate change & 0.617 & 1.620 \\
Adaptation barrier & 0.685 & 1.460 \\
Mean VIF & & 1.422 \\
\hline
\end{tabular}

The Tobit model, also called a censored regression model, was employed to estimate linear relationships among variables when there is either left or right-censoring in the dependent variable as shown in the equation below. In other words, the factors influencing climate change adaptation in the study area were estimated using Tobit regression analysis. The model was developed by Tobin (1958). Following Schwarze (2004), since the dependent variable is bounded between 0 and 1 (i.e., the variables are censored at 0.0 and 1.0), conventional regression methods fail to consider the qualitative difference between zero and continuous observations. However, the Tobit model could combine the properties of multiple regression and Probit/Logit model. Therefore, the Tobit model which was initially established for censored data was applied for the analysis. The model is specified as:

$$
\begin{gathered}
Y_{i}=\beta X_{\text {iifi } *}=\beta X i+u i>T i \\
Y_{i}=\beta 0+\beta i X i+u i
\end{gathered}
$$

where: uí $=$ normally distributed with zero mean and constant variance; $\mathrm{X}_{\mathrm{i}}=$ vector of explanatory variables; $\beta \mathrm{i}=$ vector of the parameter estimates. 
The model is fully estimated as follows:

$$
\begin{aligned}
& \mathrm{yi}^{*}=\beta 0+\beta 1 \mathrm{xi}+\varepsilon \mathrm{i}=\mathrm{xi}^{\prime} \beta+\varepsilon \mathrm{i}, \varepsilon \mathrm{i} \sim \mathrm{N}(0, \sigma 2) \\
& \text { If } y i^{*}>0=>y i=\text { climate change }=y i^{*}=x i^{\prime} \beta+\varepsilon i \\
& \text { If } \mathrm{yi}^{*} \leq 0=>\text { yi }=0\left(\mathrm{y}^{*} \text { can be negative, but if it is, } \mathrm{y}=0\right) \\
& \text { Probability Model -- } \varepsilon i \sim N(0, \sigma 2) \\
& \operatorname{Prob}(\mathrm{y}=0 \mid \mathrm{x})=\operatorname{Prob}\left(\mathrm{y}^{*} \leq 0 \mid \mathrm{x}\right)=\operatorname{Prob}\left[\left(\mathrm{y}^{*}-\mathrm{X} \beta\right) / \sigma \leq(0-\mathrm{X} \beta) / \sigma \mid \mathrm{x}\right] \\
& \operatorname{Prob}[\mathrm{z} \leq-\mathrm{X} \beta / \sigma \mid \mathrm{x}]=\Phi(-\mathrm{X} \beta / \sigma)=1-\Phi(\mathrm{X} \beta / \sigma) \\
& \operatorname{Prob}(\mathrm{y}>0 \mid \mathrm{x})=\operatorname{Prob}\left(\mathrm{y}^{*}>0 \mid \mathrm{x}\right)=1-\Phi(-\mathrm{X} \beta / \sigma)=\Phi(\mathrm{X} \beta / \sigma)
\end{aligned}
$$

$\mathrm{Yi}=$ Climate change adaptation strategies index determined by dividing the number of climate change adaptation strategies used by the individual farmers by all the climate change adaptation strategies available in the study area. Thus, the value of the climate change adaptation strategies index ranges between zero (0) and one (1). Thus, the explanatory variables used in the analysis include the socioeconomic variable of the household head and information pertaining to climate change and its adaptation, which are:

$\mathrm{X}_{1}=$ Number of years of farming (years)

$\mathrm{X}_{2}=$ Farm size (hectares)

$\mathrm{X}_{3}=$ Household size (number of persons in the household)

$\mathrm{X}_{4}=$ Gender of household head (Male $=1 ;$ Female $\left.=0\right)$

$\mathrm{X}_{5}=$ Age of household head (years)

$\mathrm{X}_{6}=$ Marital status

$\mathrm{X}_{7}=$ Household head educational level

$\mathrm{X}_{8}=$ Household head source of income

$\mathrm{X}_{9}=$ Type of farm

$\mathrm{X}_{10}=$ Who manages the farm

$\mathrm{X}_{11}=$ Who owns the farm

$\mathrm{X}_{12}=$ Land acquisition

$\mathrm{X}_{13}=$ Climate change awareness

$\mathrm{X}_{14}=$ Information receive on climate change

$\mathrm{X}_{15}=$ Source of climate change information

$\mathrm{X}_{16}=$ Climate change information through extension services

$\mathrm{X}_{17}=$ Channel of information on climate change

$\mathrm{X}_{18}=$ Support received on climate change

$\mathrm{X}_{19}=$ Climate change adaptation

$\mathrm{X}_{20}=$ Adaptation barrier

\section{Results and discussion}

The household farm size in Table 3 was statistically significant $(\mathrm{p}<0.01)$ and had a negative association. This suggests that the size of the farm had an influence on climate 
change adaptation in the study area. Farmers with small farm size tend to ignore adaptation measures as a result low resources, however, farmers with large farm size are likely to have more capacity to try out various adaptation strategies and invest in climate risk coping strategies. This could also mean that farmers reduced their farm size in other to adapt to climate change as they have little resources to cope. The larger the farm size the more the adaptation strategies of changing crop cultivars and crop types. This result is supported by Abid et al. (2015), who reported that farmers with large farm size try more adaptation options. On the contrary, Mohammed et al. (2014) reported a negative result where a large farm size requires greater levels of investment to implement adaptive strategies to climate change. The same result was explained by Acquah and Onumah (2011) that farm size was negatively significant to climate change adaptation and its effects (Fig. 2).

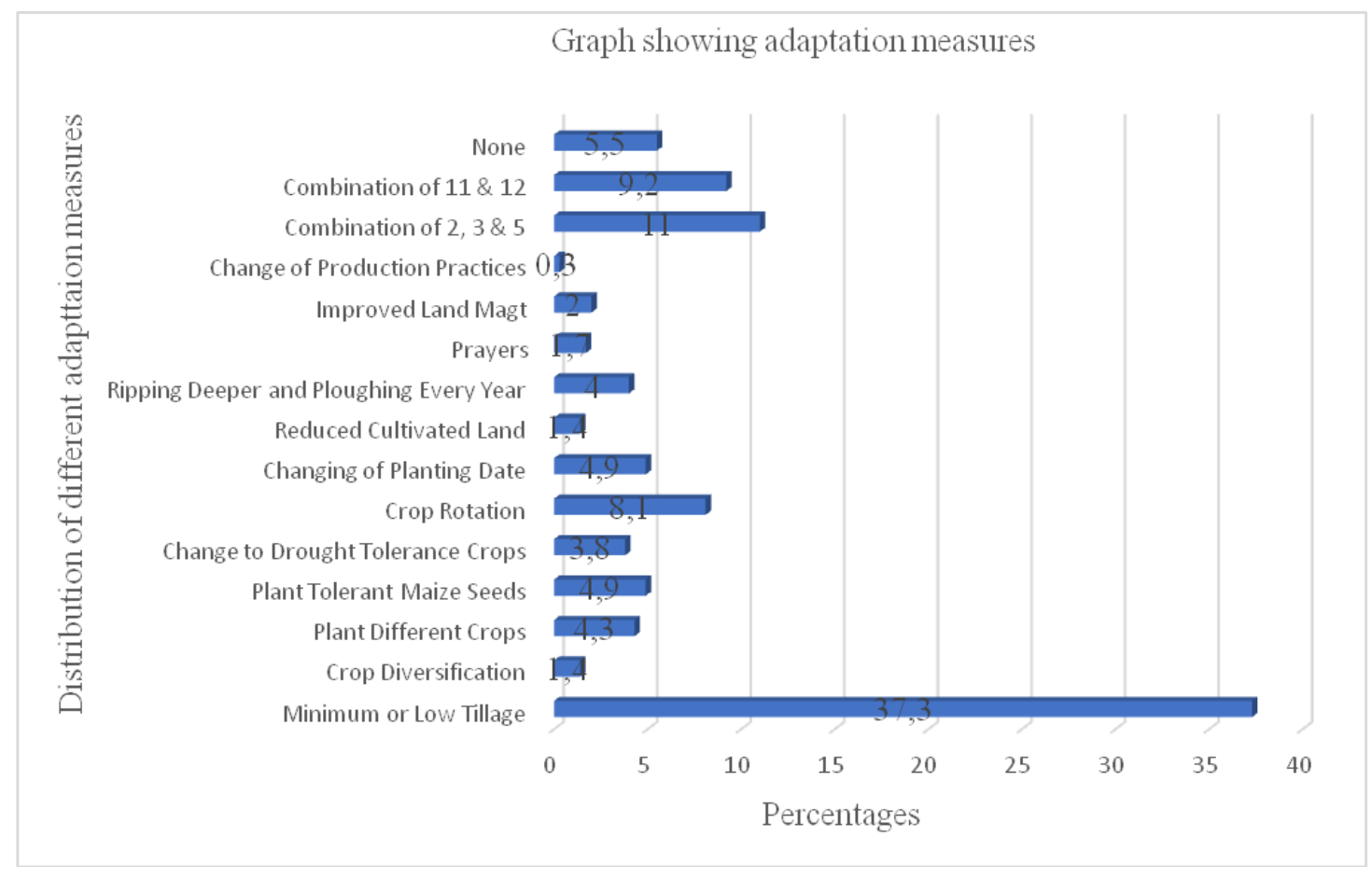

Figure 2. Distribution of different adaptation measures in the study area

According to Table 3, gender was statistically significant $(\mathrm{p}<0.01)$ and influenced climate change adaptation. Various research has revealed that gender is an important factor affecting adoption decision among farmers. The result from the study area revealed that male farmers $(84.1 \%)$ are more involved in farming and thus, adapting to climate change than women. Male farmers are more likely to perceive a change in the climatic condition unlike female farmer because male-headed households have a higher probability of acquiring information than female-headed households. This finding is supported by Ncube et al. (2016) who reported that male-headed households were more likely to perceive changes in the surrounding than female-headed households. However, Sharaunga et al. (2015) reported that empowering women in smallholder agriculture is very crucial in reducing vulnerability to climate change among rural households.

In Table 3, the type of farm a household head engage in has an influence on climate change adaptation. The type of farm in this regard includes individual farm, family 
farm, community and tribal farm which was statistically significant $(\mathrm{p}<0.05)$ to climate change adaptation. This suggests that individual farms adopt natural resources management and conservation practices better compare to tribal or community farm type as individual can manage information based on his or her household resources and needs.

Table 3. Parameter estimates (model specification) of the Tobit regression analysis on factors that influence climate change adaptation. (Source: author's computation, 2017)

\begin{tabular}{|c|c|c|c|c|c|}
\hline \multicolumn{2}{|c|}{ Variables } & Coefficient & Std. error & z- Statistic & $\operatorname{Pr}(>|\mathrm{z}|)$ \\
\hline \multicolumn{2}{|c|}{ Years of farming $\left(\mathrm{X}_{1}\right)$} & 0.006116 & 0.003868 & 1.581138 & 0.1138 \\
\hline \multicolumn{2}{|c|}{ Farm size $\left(X_{2}\right)$} & -0.013340 & 0.004865 & $-2.742015^{* * *}$ & 0.0061 \\
\hline \multicolumn{2}{|c|}{ Household size $\left(\mathrm{X}_{3}\right)$} & -0.005277 & 0.005735 & -0.920130 & 0.3575 \\
\hline \multicolumn{2}{|c|}{ Gender $\left(\mathrm{X}_{4}\right)$} & -0.062083 & 0.016218 & $-3.827976 * * *$ & 0.0001 \\
\hline \multicolumn{2}{|c|}{ Marital status $\left(\mathrm{X}_{5}\right)$} & 0.010947 & 0.006693 & 1.635506 & 0.1019 \\
\hline \multicolumn{2}{|c|}{ Education $\left(\mathrm{X}_{6}\right)$} & 0.005051 & 0.005117 & 0.987128 & 0.3236 \\
\hline \multicolumn{2}{|c|}{ Source of income $\left(\mathrm{X}_{7}\right)$} & -0.017227 & 0.015601 & -1.104226 & 0.2695 \\
\hline \multicolumn{2}{|c|}{ Type of farm $\left(\mathrm{X}_{8}\right)$} & -0.009591 & 0.004362 & $-2.198753 * *$ & 0.0279 \\
\hline \multicolumn{2}{|c|}{ Manage farm $\left(\mathrm{X}_{9}\right)$} & 0.003761 & 0.026335 & 0.142799 & 0.8864 \\
\hline \multicolumn{2}{|c|}{ Owns farm $\left(\mathrm{X}_{10}\right)$} & -0.022814 & 0.011036 & $-2.067288 * *$ & 0.0387 \\
\hline \multicolumn{2}{|c|}{ Land acquisition $\left(\mathrm{X}_{11}\right)$} & 0.009078 & 0.003044 & $2.982234 * * *$ & 0.0029 \\
\hline \multicolumn{2}{|c|}{ Climate change awareness $\left(\mathrm{X}_{12}\right)$} & 0.098297 & 0.066811 & 1.471266 & 0.1412 \\
\hline \multicolumn{2}{|c|}{ Source of climate change information $\left(\mathrm{X}_{13}\right)$} & 0.022988 & 0.007113 & $3.232000^{* * *}$ & 0.0012 \\
\hline \multicolumn{2}{|c|}{ Climate information through extension services $\left(\mathrm{X}_{14}\right)$} & 0.013465 & 0.014691 & 0.916559 & 0.3594 \\
\hline \multicolumn{2}{|c|}{ Channel of information on climate change $\left(\mathrm{X}_{15}\right)$} & 0.007942 & 0.005393 & 1.472588 & 0.1409 \\
\hline \multicolumn{2}{|c|}{ Support received on climate change $\left(\mathrm{X}_{16}\right)$} & -0.005196 & 0.002948 & $-1.762625^{*}$ & 0.0780 \\
\hline \multicolumn{2}{|c|}{ Adaptation barrier $\left(\mathrm{X}_{17}\right)$} & -0.190419 & 0.006259 & $-30.42514 * * *$ & 0.0000 \\
\hline \multicolumn{2}{|c|}{$\mathrm{C}$} & 0.203205 & 0.277651 & 0.731872 & 0.4642 \\
\hline \multicolumn{6}{|l|}{ Error distribution } \\
\hline SCALE: C (19) & 0.099657 & \multicolumn{2}{|c|}{0.003788} & 26.30651 & 0.0000 \\
\hline Mean dependent var & 1.057803 & \multicolumn{2}{|c|}{ S.D. dependent var } & 0.233709 & \\
\hline S.E. of regression & 0.102511 & \multicolumn{2}{|c|}{ Akaike info criterion } & -1.664344 & \\
\hline Sum squared resid & 3.436285 & \multicolumn{2}{|c|}{ Schwarz criterion } & -1.453124 & \\
\hline Log likelihood & 306.9315 & \multicolumn{2}{|c|}{ Hannan-Quinn criterion } & -1.580235 & \\
\hline Avg. log likelihood & 0.887085 & & & & \\
\hline \multicolumn{6}{|l|}{ Wald test equation } \\
\hline Test statistic & Value & $\overline{\mathrm{df}}$ & & Probabil & \\
\hline F-statistic & 91.26040 & $(17,3$ & 327) & 0.0000 & \\
\hline Chi-square & 1551.427 & 17 & & 0.0000 & \\
\hline
\end{tabular}

$\mathrm{p}<0.1(*) ; \mathrm{p}<0.05(* *) ; \mathrm{p}<0.01(* * *)$ at $10 \%, 5 \%$ and $1 \%$ level of significance, respectively

In the same train of thought, Table 3 revealed that an individual who owns the farm was statistically significant $(\mathrm{p}<0.05)$ and influence climate change adaptation strategies. This result implied that the knowledge and experience of the farm owner determine the adoption of natural resources management and conservation practices to use. Research by Habtemariam et al. (2016) reported that educated and experienced farmers are expected to have more knowledge and information about climate change 
and adaptation measures to use in response to climate challenges. Theis et al. (2018) reported that land ownership individually managed, is widely believed to encourage the adoption of technologies linked to physical assets such as land and irrigation system.

The land is a fundamental factor of production. The method of acquiring land or farm by the farmers was statistically significant $(\mathrm{p}<0.01)$ and influence climate change adaptation in the study area as shown in Table 3. Various methods of land acquisition as identified in the study area include; land redistribution for agricultural development (LRAD), PLAS, land affair, hire, inheritance, own finance. This result implies that adaptation strategies are linked to land acquisition method. Farmers who buy land hire or through land affair tend to adopt adaptation strategies more as they need to produce much in other to pay and make a profit to sustain a livelihood.

The sources of information received on climate change influence adaptation strategies. In Table 3, the information source was statistically significant $(\mathrm{p}<0.01)$ where the majority of the respondents in the study area obtained information through media (radio). The source of information influence climate change adaptation because the information from non-reputable source might not be the right information needed to adapt in other to transform or increase food production, and different information target different environment and farming systems. In addition, the source from which information is being received determines the effectiveness and farmers' adoption. According to Akinnagbe et al. (2015), it was reported that crop farmers got their information from sources which may not be unconnected with their level of interaction in the communities. Farmers need information in which extension officers play a significant role (Gabriel et al., 2013).

According to Table 3, the support received by the farmers was statistically significant $(\mathrm{p}<0.1)$. The support received includes; formal credit, insurance, farmer to farmer extension, relatives, subsidies. Adaptation to climate change becomes easier when farmers receive support on climate change. The inability of the farmers to get the necessary support and resources might hinder the farmers from adapting to climate change. According to UNDP (2018), it was emphasized that most farmers in Africa are operating under resource limitation which prevents adaptation measures. Derr (2018) reported that institutional support for climate change adaptation is needed for rural farmers in order to adapt to climate change scenario and events.

In Table 3, the adaptation barrier was statistically significant $(\mathrm{p}<0.01)$ and influence climate change adaptation in the study area. Barriers to adaptation restrict people's ability to address the negative impacts of climate change. Examples of adaptation barrier in the study area are lack of knowledge and education, lack of structural and infrastructural resources, lack of capital resources and extension officers. Adaptation barriers prevent farmers from adopting various strategies and practices to cope with the impact of climate change variability and events. Farmers need resources and information to be able to adapt without which farm productivity is affected. This result was supported by Brown and Sonwa (2015), who reported that in agricultural communities, lack of financial capital is one barrier to adaptation, such as the adoption of improved crop varieties and diversification of livelihoods.

\section{Conclusion and recommendation}

The study reveals that climate change poses several challenges to the livelihoods of rural households in the study area. It also provides a comprehensive understanding of 
the factors that hinders adaptation to climate change in the study area, which includes; farm size, household gender, type of farms, who owns the farm, land acquisition, source of climate change information, support received on climate change, and adaptation barrier. This study highlights that fostering climate change adaptation does not only entails scientific knowledge especially in the study area (SSA) but also community involvement and development of solutions using local approach and socio-economic characteristics of the rural household. The recommendation drawn from this study is that in attempting to support households' adaptation strategies to climate change, and develop sustainable strategies that will be culturally accepted by rural households and communities, considerable attention should be paid to understanding socio-economic factors such as farm size, household gender, type of farms, who owns the farm, land acquisition, and also information on climate change.

Acknowledgments. We like to express our sincere gratitude to the anonymous reviewers for improving the quality of this paper. We also acknowledge the support of those who have contributed to the success of this paper. We acknowledge the funding provided by the University of South Africa.

Conflict of interests. The authors declare that there is no conflict of interests.

\section{REFERENCES}

[1] Abid, M., Scheffran, J., Schneider, U. A., Ashfaq, M. (2015): Farmers' perceptions of and adaptation strategies to climate change and their determinants: the case of Punjab Province, Pakistan. - Earth System Dynamics 6(1): 225-243. doi.org/10.5194/esd-62252015.

[2] Acquah, H. D., Onumah, E. E. (2011): Farmers' perception and adaptation to climate change effects: A willingness to pay. - J. Sustain. Dev. Afr. 13: 150-161.

[3] Adebayor, A. A. (2012): Evidence of climate change in Taraba State: a preliminary report. - A paper presented at the Faculty of Science Seminar Series held at the Lecture Hall on 13th September 2012. Taraba State University, Jalingo, Nigeria.

[4] Akinnagbe, O. M., Attamah, C. O., Igbokwe, E. M. (2015): Sources of information on climate change among crop farmers in Enugu North Agricultural Zone, Nigeria. International Journal of Research in Agriculture and Forestry 2(11): 27-33.

[5] Blignaut, J., Liza, U., James, A. (2009): Agriculture production's sensitivity to changes in climate in South Africa. - South African Journal of Science 105(1-2).

[6] Brown, H. C. P., Sonwa, D. J. (2015): Rural local institutions and climate change adaptation in forest communities in Cameroon. - Ecology and Society 20(2): 6: 4-8. doi.org/10.5751/ES-07327-200206.

[7] Butler, C. D. (2018): Climate change, health, and existential risks to civilization: a comprehensive review (1989-2013). - International Journal of Environmental Research and Public Health 15(10): 2266. DOI: 10.3390/ijerph15102266.

[8] Davis, C. L., Hoffman, M. T., Roberts, W. (2016): Recent trends in the climate of Namaqualand, a mega diverse arid region of South Africa. - S Afr J Sci 112(4): 9. doi.org/10.17159/ sajs.2016/20150217.

[9] Derr, T. (2018): Climate change perceptions and adaptation among small-scale farmers in Uganda: a community-based participatory approach. - A thesis submitted in partial fulfillment of the requirements for the degree of Master of Science in geography at The University of Utah State University Logan, Utah, pp. 22-83.

[10] Food and Agriculture Organization of the United Nations (2016): The State of Food and Agriculture. Climate Change, Agriculture and Food Security. -FAO, Rome. 
[11] Gabriel, D., Sait, S. M., Kunin, W. E., Benton, T. G. (2013): Food production vs. biodiversity: comparing organic and conventional agriculture. - J Appl Ecol 50: 355-364. DOI: $10.1111 / 1365-2664.12035$.

[12] Habtemariam, L. T., Gandorfer, M., Kassa, G. A., Heissenhuber, A., München, T. U. (2016): Reference tools. - Environmental Management. doi.org/10.1007/s00267-0160708-0.

[13] IPCC (2014): Climate Change 2014: Impacts, Adaptation and Vulnerability. Summary for Policy Makers. - Cambridge University Press, Cambridge.

[14] Kiker, G. A. (2015): South African County Study on Climate Change Synthesis Report for the Vulnerability and Adaptation (V\&A) Section of the South African Climate Change, Vulnerability and Adaptation Assessment. - School of Bioresources Engineering and Environmental Hydrology, University of Natal, Durban, South Africa..

[15] Linus, B. G., Sogbesan, O. A., Ekundayo, T. M., Kesonga, G. M. (2014): Fishing communities and fishing as livelihoods in Adamawa state. - Direct Research Journal of Agriculture and Food Science 2(11): 195-204.

[16] Mohammed, N. U., Wolfgang, B., Jason, S. E. (2014): Factors affecting farmers' adaptation strategies to environmental degradation and climate change effects: a farm level study in Bangladesh. - Climate Change 2: 223-241. DOI: 10.3390/cli2040223.

[17] Ncube, M., Madubula, N., Ngwenya, H., Zinyengere, N., Zhou, L., Francis, J., Madzivhandila, T. (2016): Climate change, household vulnerability and smart agriculture: the case of two South African provinces. - Jamba (Potchefstroom, South Africa) 8(2): 182. DOI: $10.4102 /$ jamba.v8i2.182.

[18] Niang, I., Ruppel, O. C., Abdrabo, M. A., Essel, A., Lennard, C., Padgham, J., Urquhart, P. (2014): Africa. - In: Climate Change 2014: Impacts, Adaptation, and Vulnerability. Part B: Regional Aspects. Contribution of Working Group II to the Fifth Assessment Report of the Intergovernmental Panel on Climate Change. Cambridge University Press, Cambridge, UK.

[19] Ochieng, J., krimi, L., Mathenge, M. (2016): Effect of Climate Variability and Change on Agricultural Production: The Case of Small Scale Farmers in Kenya. - Tegemeo Institute of Agricultural Policy and Development, Egerton, Kenya. doi.org/10.1016/j.njas.2016.03.005.

[20] Osumanu, I. K., Aniah, P., Yelfaanibe, A. (2017): Determinants of adaptive capacity to climate change among smallholder rural households in the Bongo District, Ghana. Ghana Journal of Development Studies 14(2): 143-145. doi.org/10.4314/gjds.v14i2.8.

[21] Pereira, L. (2017): Climate change impacts on agriculture across Africa. Subject: environmental issues and problems. - Agriculture and the Environment. DOI: 10.1093/acrefore/9780199389414.013.292.

[22] Schwarze, S. (2004): Determinants of Income Generating Activities of Rural Households: A Quantitative Study in the Vicinity of Love-Lindu National Park in Central Sulawesi, Indonesia. - Institute of Rural Development. University of Goettingen, Goettigen.

[23] Sharaunga, S., Mudhara, M., Bogale, A. (2015): The impact of 'women's empowerment in agriculture' on household vulnerability to food insecurity in the KwaZulu-Natal Province. - Forum for Development Studies 42(2): 195-223. doi.org/10.1080/08039410.2014.997792.

[24] Sensako (2015): South Africans forced to import maize as drought destroys crops. http://www.sensako.co.za/NewsArticle.aspx?id=8 (accessed on 13 May 2019).

[25] South African Agricultural Baseline (2011): Maize Production. - Department of Agriculture of South Africa, Jean du Plessis, Bureau for Food and Agricultural Policy (BFAP). https://www.syngenta.co.za/maize (accessed on 10 October 2017).

[26] Theis, S., Lefore, N., Meinzen-Dick, R., Bryan, E. (2018): What happens after technology adoption? Gendered aspects of small scale irrigation technologies in Ethiopia, 


$$
-11272 \text { - }
$$

Ghana, and Tanzania. - Agriculture and Human Values 35: 671-684. doi.org/10.1007/s10460-018-9862-8.

[27] Tobin, J. (1958): Estimation of relationships for limited dependent variables. Econometrica 26: 2436.

[28] UNDP (2018): Climate Change Adaptation in Africa UNDP. Synthesis of Experiences and Recommendations. - UDNP, New York, pp. 6-87. https://www.thegef.org/sites/default/files/publications/CCA-Africa-Final.pdf (accessed on 13 May 2019).

[29] Winifred, C., Nancy, W., Mungai, S. S., Hillary, K., Bett, H. L. (2018): "Farmers' perspectives: impact of climate change on African indigenous vegetable production in Kenya". - International Journal of Climate Change Strategies and Management 10(4): 551-579. doi.org/10.1108/IJCCSM-07-2017-0160. 